\title{
A Coherent Inconsistency: Italian Cultural Diplomacy in Palestine, 1918-1938
}

\author{
Roberto Mazza
}

A recent report of the Italian NGO COSV (Coordinamento delle Organizzazioni per il Servizio Volontario) suggests that "it was not until the 1995 Euro-Mediterranean Conference that Italy began to take on a prominent role in the Mediterranean region". ${ }^{1}$ It is possible Italy lagged behind other countries in the development of cultural diplomacy, nevertheless Italian cultural influence in the Mediterranean, and in Palestine in particular, certainly predates 1995. Studies of European cultural policies in Palestine have often focused on Britain, France and occasionally Germany, however very little scholarship has been dedicated to Italy. The works of Nir Arielli, Daniela Fabrizio, Lucia Rostagno and Arturo Marzano shed light on some aspects of early Italian cultural diplomacy and relations in Mandatory Palestine. ${ }^{2}$ Yet the literature available, but more importantly the research currently carried out on this topic, is rather scant and often unclear on how cultural diplomacy should be defined. The lack of sources has certainly been one reason behind

\footnotetext{
${ }^{1}$ Organisation for the coordination of volunteering services; last modified May 9, 2018, http://www.cosv.org/.

${ }^{2} \mathrm{Nir}$ Arielli, Fascist Italy and the Middle East 1933-40 (London: Palgrave Macmillan, 2010); Daniela Fabrizio, Identita' Nazionali e Identita' Religiose (Rome: Studium, 2004); Arturo Marzano, Onde Fasciste. La Propaganda Araba di Radio Bari 1934-43 (Rome: Carocci, 2015); Lucia Rostagno, Terrasanta o Palestina? La Diplomazia Italiana e il Nazionalismo Palestinese (1861-1939) (Rome: Bardi, 1996).
}

R. Mazza $(\bowtie)$

University of Limerick, Limerick, Ireland

e-mail: Roberto.Mazza@ul.ie

(C) The Author(s) 2021

K. Sanchez Summerer and S. Zananiri (eds.), European Cultural

Diplomacy and Arab Christians in Palestine, 1918-1948,

https://doi.org/10.1007/978-3-030-55540-5_16 
this shortage of studies, however the problematic definition of cultural diplomacy has also kept scholars away from potential complications. Nevertheless, as the material of the Italian consulate in Jerusalem from its opening in the 1860s to the 1940s has been made accessible, it will be possible to add important contributions and preliminarily assess Italian cultural diplomacy in Palestine, its effectiveness and legacy—if any-over the local population: Arab and Jews in their multiplicity of identities and organisations.

What role did culture play in the policies of European agents-governmental and non-regarding the Arabs and Jews of Palestine? With this chapter I will try to answer this question looking at the work of Italian diplomacy in Palestine from 1918 to the mid-1930s, essentially from the establishment of British rule to the outbreak of the Arab Revolt which marked a major shift in the local and international political atmosphere. Looking at the material of the Italian consulate in Jerusalem and its subsidiaries throughout Palestine, this chapter will attempt to reconstruct Italian cultural activities particularly designed to promote linguistic and cultural agendas. Italians followed similar paths to their French rivals in the establishment of educational institutions. ${ }^{3}$ More importantly, from the establishment of the Fascist regime in 1922, Mussolini attempted to support Arab nationalism and Zionism at the same time with the purpose of challenging British rule in Palestine and creating a stronger Italian presence and influence in the region. Italian cultural diplomacy was then used as a proxy in order to create support for Italian expansion, rather than producing genuine cultural relations.

In this chapter I look at consular records in order to highlight several case studies with the purpose of seeing how Italian cultural diplomacy developed in the region, its transformations, inconsistencies and ultimate failure. Italian cultural policies, however, cannot be understood and analysed in a vacuum; they must be contextualised within the broader cultural activities promoted by "Italian" religious institutions. While the Italian State and the Catholic Church were not just officially separated, but in a state of conflict, their relationship was much more blurred and entangled outside the borders of Italy. In other words, often the distinction between Italian and Roman Catholic was rather indistinguishable, allowing the secular cultural diplomacy of the state to mingle with the religious-cultural activities of Italian Catholic institutions in Palestine, producing a hybrid form of cultural diplomacy.

While this chapter will mostly rely on the material of the Italian consulate in Jerusalem, I will also integrate evidence from religious institutions including the Latin Patriarchate and the Custody of the Holy Land. As secondary literature is rather thin, I will attempt to introduce a model for studying Italian cultural diplomacy which must take into account the general diplomatic leverage. For instance, considering that from 1919 to 1926 seven

${ }^{3} \mathrm{~A}$ good work showing the various French activities is Dominique Trimbur and Ran Aaronsohn, de Bonaparte a' Balfour. La France, l'Europe occidentale et la Palestine, 1799-1917 (Paris: CNRS Editions, 2008). 
different consuls led the Italian consulate, we understand that Italian leverage was minimal. However, with the appointment of Mario Zanotti Bianchi, and later of Orazio Pedrazzi and Mariano de Angelis-covering the period from 1926 to 1936-Italian diplomacy became more relevant and visible. While Italian cultural activities may have become more regular, they did not necessarily prove to be effective. Retrospectively we know that Italian influence did not break through as desired, nevertheless it cannot be underestimated or neglected: it is not the outcome that matters here, but the journey.

\section{In Search of a Working Definition of Cultural Diplomacy}

According to Michael Waller, cultural diplomacy is a kind of soft power that includes the "exchange of ideas, information, art, language and other aspects of culture among nations and their peoples in order to foster mutual understanding". ${ }^{4}$ In the contemporary world cultural diplomacy is a rather loose term defining a set of practices by nation states in their relations. ${ }^{5}$ The purpose is ultimately to influence a foreign audience with the hope of achieving different goals including cooperation between nations, prevention of conflict and building positive views of one another's countries. Though cultural diplomacy is a fascinating concept, one that may be very useful in understanding contemporary relations between Israel, Palestine and the rest of the world, I believe it is a concept that cannot be easily applied to the historical case presented in this chapter. Cultural diplomacy is based on a two-way dialogue, maybe an unbalanced one, yet it presumes a form of dual exchange between peers.

In order to problematise and contextualise Italian diplomacy in Palestine within a theoretical framework I believe the concept of soft power, coined by Joseph Nye, better frames the policies adopted by the Italian government and executed at a local level by the Italian consuls in Jerusalem. In a nutshell soft power is the ability to shape the preferences of others: this is not merely a form of influence, but more a method of persuasion or a way to move people by argument. ${ }^{6}$ Culture is indeed a form of soft power, however, as noted by some scholars, cultural attractiveness is not soft power on its own, it is a resource deployed in order to achieve defined objectives. ${ }^{7}$ In other words

\footnotetext{
${ }^{4}$ Michael J. Walter, "Cultural Diplomacy, Political Influence, and Integrated Strategy," in Strategic Influence: Public Diplomacy, Counterpropaganda, and Political Warfare, ed. M. J. Waller (Washington, DC: Institute of World Politics Press, 2009), 74.

${ }^{5}$ A good summary on the state of the research is provided by Jessica C. E. Gienow-Hecht and Mark C. Donfried, "The Model of Cultural Diplomacy," in Searching for a Cultural Diplomacy, eds. Jessica C. E. Gienow-Hecht and Mark C. Donfried (Oxford: Berghahn Books, 2010), $13-16$.

${ }^{6}$ Joseph Nye, Soft Power. The Means to Success in World Politics (Cambridge: Perseus Books, 2004), 5-6.

${ }^{7}$ Ien Ang, Yudihishthir Isar, and Philip Mar, "Cultural Diplomacy: Beyond the National Interest?" International Journal of Cultural Policy 21, no. 4 (2015): 368.
} 
opening Italian schools in Palestine or producing pro-Arab propaganda may have been a form of cultural attraction but unless it reached the goals set by Italian policymakers, it was not soft power per se. It will be argued later that this was the limit of Italian cultural diplomacy in Palestine: the deployment of cultural resources was contingent on the inconsistency of the proposed goals, therefore they never converted into visible forms of soft power. Essentially, Italians confused cultural resources with the behaviour of attraction and, as Joseph Nye argued, "excellent wine and cheese do not guarantee attraction to France", so good schools and entertaining broadcasts on Radio Bari did not give the Italians the edge over the British. ${ }^{8}$

At this point, it is quite clear that in order to frame Italian cultural diplomacy in Palestine, the given definitions are not entirely useful, and they must be adapted to the context. Italian attempts at influencing Palestinians were indeed a form of one-directional cultural diplomacy: Italians were not interested in cultural exchange. This is not to dramatically diminish the value of the attempts made, but as we will see later, the range of cultural tools employed were never consistently coordinated or arranged in order to achieve the goals set. My belief is that there were no clear goals in the first place, and in turn this inconsistency produced a random set of cultural policies that may have influenced individuals but never reached the potential to impact upon a larger community.

More radically I would even question the nature of cultural diplomacy in this context as I am not entirely sure this is diplomacy at all; it looks more a form of covert imperialism than anything else. If we look at the question of agency it is not clear "who is in charge": the state, the Church, individuals, consuls or others? However, for the lack of a better term, in this chapter I refer to cultural diplomacy, bearing in mind its intriguing usefulness and limitations. The examples discussed in this chapter show that Italian cultural diplomacy was reactive instead of pro-active. For instance, the Alliance Française, established in 1883 , was created with the purpose of teaching French as a language that would inspire in other people an affinity for France and above all for the values of the enlightenment; on the other hand the Dante Alighieri Society established in 1889 was designed to promote Italian culture and language around the world, especially among the expatriate Italian community. ${ }^{9}$ The substantial difference is that while the first pro-actively sought to influence foreign communities, the latter was instead created as a reaction to Italian migration and the potential loss of national identity. While it would be impossible to make a more substantial contribution to the

\footnotetext{
${ }^{8}$ Nye, Soft Power, 12.

${ }^{9}$ Gienow-Hecth and Donfried, "The Model of Cultural Diplomacy," 18; Daniela Fabrizio, Fascino D'Oriente. Religionie Politica in Medio Oriente da Giolitti a Mussolini (Genoa: Marietti, 2006), 282-283. On the Dante Alighieri see also T. Van Kessel, Foreign Cultural Policy in the Interbellum: The Italian Dante Alighieri Society and the British Council Contesting the Mediterranean (Amsterdam: Amsterdam University Press, 2016).
} 
debate over cultural diplomacy and policies, I suggest that in the end, Italian cultural policies were enacted with the purpose of strengthening Italian national identity rather than projecting national power abroad. ${ }^{10}$

\section{The Italian Consulate in Jerusalem: A Short History}

An Italian presence has been visible for centuries in Jerusalem in the form of clergy and pilgrims; however, the size of this community did not match its political relevance, which was overshadowed by British and French consulates and communities, echoing the relative unimportance of Italy on the international stage. The Italian presence in Palestine has been mainly analysed through three lenses: the history of Italian religious institutions and personnel operating in the Holy Land; the attitude of Italian governments towards Palestine and, after 1948, their relationship with Israel and the Arab countries; lastly some scholars have looked at Italian relations with the Yishuv. ${ }^{11}$ Few works have been devoted to the study of the political, economic, social and religious networks established by the Italian state in Palestine and the connections between the consulate and the complex system of power in Jerusalem and the region. ${ }^{12}$ The lack of historiographical research in Italian and other languages is not only a reflection of the absence of primary sources before the inventory of the consulate records, but also of the tendency-particularly evident in the historiography on Jerusalem and Palestine-to differentiate and separate the subjects of study into a fragmented picture rather than providing an interconnected and wider portrait.

In the only work dedicated to Italian diplomacy in Palestine, Lucia Rostagno was right to suggest that we should bear in mind that from Italy, Palestine was hard to reach and not included in the colonial dreams of the new Italian state, and certainly not a destination for Italian migrants. ${ }^{13}$ At the end of the nineteenth century, Italian interests towards Palestine were mainly devotional. In fact, it can safely be said that little was known of the

${ }^{10}$ J. P. Singh, "Global Cultural Policies and Power," in International Cultural Policies and Power, ed. J. P. Singh (London: Palgrave Macmillan, 2010): 11.

${ }^{11}$ See Giuseppe Buffon, Les Franciscains en Terre Sainte (1869-1889). Religion et politique: une recherche institutionelle (Paris: Cerf, 2005); Paolo Pieraccini, Cattolici di Terra Santa (13332000) (Florence: Pagnini e Martinelli, 2003); Andrea Giovannelli, La Santa Sede e la Palestina: La Custodia di Terra Santa tra la fine dell'impero ottomano e la guerra dei sei giorni (Rome: Studium, 2000); Arturo Marzano, Una terra per rinascere: Gli ebrei italiani e l'emigrazione in Palestina prima della guerra (1920-1940) (Genoa: Marietti, 2003); Luca Riccardi, Il "problema Israele": Diplomazia italiana e PCI di fronte allo stato ebraico (1948-1973) (Milan: Guerini e Associati, 2006); Sergio I. Minerbi, Il Vaticano, la Terra Santa e il Sionismo (Milan: Bompiani, 1988); Silvio Ferrari, Vaticano e Israele dal secondo conflitto mondiale alla guerra del Golfo (Florence: Sansoni, 1991).

${ }^{12}$ Rostagno, Terrasanta o Palestina?; Andrea Gabellini, L'Italia e l'assetto della Palestina (1916-1924) (Florence: Societá per gli studi sul Medio Oriente, 2000).

${ }^{13}$ Rostagno, Terrasanta o Palestina? 12. 
country: Italian Catholics and Jews did not share the same interest in the Holy Land as their British, French, or American coreligionists. ${ }^{14}$ The re-establishment of the Latin Patriarchate of Jerusalem in 1847 might have had triggered a renewed interest, although available evidence does not suggest this, and in any case the Terrasanta was an entity to pray for, not to conquer. ${ }^{15}$ Italy had no connection whatsoever with the local Eastern Catholic churches-a field left open to the French. The Italian governments saw indigenous Catholics as a catalyser to promote and defend the Italian character of the Latin Patriarchate and the Custody of the Holy Land (both the Patriarch and the Custos were in fact Italian subjects). ${ }^{16}$ The Salesians had a substantial impact in Palestine, working with local inhabitants. Similarly, the Franciscans, by far the largest Catholic group in Palestine, provided jobs and services to local Christians, Muslims and Jews alike. Politicians and diplomats were still far away. ${ }^{17}$

In 1843, Consul Lenchantin from the Kingdom of Piedmont and Sardinia was sent to Jerusalem to protect the interests of its subjects and to challenge the French protectorate over Catholics. ${ }^{18}$ The material available at the state archives in Turin has barely been perused by scholars and, together with the material recently uncovered at the archives of the Italian foreign ministry, may paint a different picture; however, it is safe to say that until 1849-when the consulate was "temporarily" closed-Italian diplomatic presence had limited influence. ${ }^{19}$ Adolfo Castellinard, the second Sardinian-Piedmontese consul, left Jerusalem in 1849. The seat remained vacant and was filled again only a decade after the Italian unification process was completed.

The newly created Kingdom of Italy could not afford a wide and sophisticated diplomatic network. The lack of trained and trusted diplomatic officials was paired with the imperative on Minister of Finance Quintino Sella to avoid

\footnotetext{
${ }^{14}$ It is important to highlight that though Italians were not interested in relocating to Palestine, attention to the Holy Land was voiced through Vatican publications. It is often hard to differentiate between Vatican and Italian sources as both were written in Italian and Catholics were split over loyalty to the State or the Church. See also Paolo Maggiolini's chapter in this volume.

${ }^{15}$ See Paolo Pieraccini, Il ristabilimento del patriarcato latino di Gerusalemme e la custodia di Terra Santa. La dialettica istituzionale al tempo del primo patriarca mons. Giuseppe Valerga (1847-1872) (Cairo: Franciscan Center of Christian Oriental Studies, 2006).

${ }^{16}$ See Giovannelli, La Santa Sede.

${ }^{17}$ Simonetta della Seta, "La Presenza e l'Opera dei Salesiani in Palestina," Storia Contemporanea 20, no. 1 (1989): 81-101.

${ }^{18}$ Archivio Storico Diplomatico del Ministero degli Affari Esteri (ASDMAE) Consolato Gerusalemme, Pacco 1 (old catalogue), note written in 1897 with a short history of the consuls in Jerusalem. Details of Lenchantin can be found in Giuseppe Alessandro Piola Caselli, Cronache Marinare (1843-1883), ed. Federico Adamoli, www.piolacaselli.altervista.org/cronache-marinare/Cronache\%20Marinare\%20con\%20Indice.pdf.

${ }^{19}$ Material related to the Consulate of the Kingdom of Sardinia and Piedmont in Jerusalem can also be found in ASMAE, Consolato Gerusalemme, Pacco 9 (old catalogue).
} 
a deficit in the budget of the nascent state. However, members of the Italian parliament were fully convinced of the necessity of opening a consulate in the holy city. ${ }^{20}$ Eventually, an agreement was made, and Vice-Consul Alessandro de Rege di Donato was appointed consul in Jerusalem on 15 November 1871. Like his seven successors until the outbreak of the First World War, di Donato had no deep knowledge of the region, or its languages, religions and peoples. It must be said, however, that the earliest Sardinian consuls had more experience in the region, as both Lenchantin and Castellinard had served as consuls in the Ottoman Empire before their appointment to Jerusalem. ${ }^{21}$ It was only in 1911 , with the impeding Italian invasion of Libya, that the Italian Orientalist Leone Caetani passionately petitioned the Italian parliament and the foreign ministry to support the Oriental Institute in Naples as a place to forge young diplomats serving in the East. ${ }^{22}$ Rostagno suggests that the existing consuls had no interest in local society, which never featured in their reports; however, new material may readdress this view and paint a more nuanced picture. A local dimension seems to emerge in the registers of correspondence with Constantinople, as many letters deal with local issues, particularly complaints against petty crime committed by local inhabitants. $^{23}$

A major change occurred with the appointment of Carlo Senni in May 1907. Though not an Orientalist, the young consul was a careful observer and, in his reports, gathered increasing amounts of information about the local communities and their intra- and interrelations. ${ }^{24}$ Senni reported on indigenous religious communities at length, offering suggestions on how to engage with them. Some of his comments may look naïve or poorly informed, as he did not possess a deep knowledge of local politics. However, the fact that he was not involved in any major local dispute or in any major scheme to control one or more groups provides a perspective that can contribute nuance to what we know of local politics and dynamics. ${ }^{25}$ Senni also provides invaluable information about Jerusalem during the First World War, as he remained in the city until the spring of 1915 , reporting on a variety of

${ }^{20}$ Rostagno, Terrasanta o Palestina? 22-23.

${ }^{21}$ See Adamoli, Cronache Marinare.

${ }^{22}$ Rostagno, Terrasanta o Palestina? 27.

${ }^{23}$ ASDMAE, Consolato Gerusalemme, Pacco 3 (old catalogue), Resigter Correspondence with Constantinople 1872-1892. Some miscellaneous registers in the same folder suggest a growing interest in the local economy, as more Italians became interested in opening businesses or dealing with local businessmen. However, the scope of this commercial activity at the end of the nineteenth century was small compared to other European countries.

${ }^{24}$ Details of Carlo Senni can be found at: notes9.senato.it/web/senregno.nsf/d973a7c86861 8f05cl25711400382868/ea6b98faa6aaa56a4125646f0060866f? OpenDocument, last modified March 21, 2017.

${ }^{25}$ See ASDMAE, Consolato Gerusalemme, Pacco 8 (old catalogue), Local and Foreign Religious Communities. 
subjects. ${ }^{26}$ As Senni left Jerusalem upon the Italian declaration of war against the Ottoman Empire, it is possible to say that he made the Italian presence in the region more relevant and at the same time brought Jerusalem and Palestine closer to Italy and Italians.

With the end of the war, Senni returned to Jerusalem for a short time, but everything had changed. Now the British were in control and the Italian government was involved in redrawing the Middle East. Despite the increased role of Italian diplomacy in Palestine, both the British and French marginalised Italy, which they saw more as a nuisance than a challenge. ${ }^{27}$ Italian diplomacy, meanwhile, was unable to react quickly to the changes occurring in Palestine. Between 1919 and 1926, seven different consuls led the Italian consulate. Copies of the reports sent to Rome show the lack of diplomatic initiative and a generally superficial understanding of events unfolding in Palestine and Jerusalem, including the emerging national struggle between Arabs and Zionists. This diplomatic weakness was a reflection of Italian politics, as the fascist regime was slowly taking over. It is in 1926, with the appointment of Mario Zanotti Bianchi, that Italian diplomatic efforts became more substantial and visible. ${ }^{28}$

Jerusalem and Palestine came to play a more important role for Italian diplomacy and politics. As Mussolini aimed at extending Italian influence over the Mediterranean as part of his dream to make Italy an empire, Palestine became a battleground against British influence in the region. ${ }^{29}$ One of the most interesting consuls yet to be fully analysed is Orazio Pedrazzi. Appointed in February 1927, Pedrazzi was not a diplomat by profession, but a journalist and an expert on Middle Eastern politics. He probably had a direct line to Mussolini and in his short tenure he emphasised the necessity of working with the Zionists, as they were going to dictate the future of Palestine. Though he was an anti-Zionist and Arabophobe, his main concern was to challenge British rule and thus he lost his job rather quickly. After Pedrazzi left, on the eve of the Western Wall riots of 1929, Mussolini changed direction and his support for the Arab-Palestinian cause became more visible in terms of propaganda and help for local Palestinian elites. It would be interesting to discover in the papers of the consulate in Jerusalem the extent and quality of Italian-Zionist relations, which certainly did not altogether cease. ${ }^{30}$

The man who helped bring some local Arabs to the Italian side was Mariano De Angelis. Appointed consul in 1932, De Angelis served until

\footnotetext{
${ }^{26}$ See ASDMAE, Consolato Gerusalemme, Pacco 10 (old catalogue), various correspondence in relation to the outbreak of the First World War.

${ }^{27}$ Gabellini, L'Italia e l'assetto della Palestina.

${ }^{28}$ Rostagno, Terrasanta o Palestina? 136.

${ }^{29}$ Arielli, Fascist Italy.

${ }^{30}$ Arielli, Fascist Italy, 20-21.
} 
1936 and worked publicly and secretly to transform anti-Italian sentiments among the Arabs into feelings of sympathy. At the same time, De Angelis looked with favour on Jabotinsky and his hard-line Zionists. Though Mussolini never met Jabotinsky, it would be interesting to discover more about this relationship. ${ }^{31}$ Many works have dealt with the emergence of the alliance between Mussolini and the Mufti of Jerusalem, al-Hajj Amin al-Husayni, and it is clear that Mussolini had to adopt different policies in Libya and show a stronger commitment towards Arabs and Muslims in order to gain his friendship and to transform anti-Italian sentiments. By 1933, De Angelis had a good relationship with the Mufti, and we hope the papers available in Rome may give us more details about the ways in which the shift occurred. De Angelis also wrote extensively about the possibility of an agreement between the Arabs and the Zionists and he hoped to see Mussolini become a peacemaker. ${ }^{32}$

De Angelis left on the eve of the 1936-1939 revolt and Quinto Mazzolini succeeded him until the consulate was closed with the outbreak of the war between Italy and Great Britain. The years of the Revolt marked strong Italian support for the Palestinian cause, but Italian propaganda was ultimately unsuccessful in turning the Palestinians against the British. The example of Radio Bari is illuminating: Arabic-language radio broadcasts targeting Palestine and Transjordan were heavily criticised by the British, who feared the local population's rebellion against colonial power. But though Arab listeners enjoyed programs in Arabic, it is also true that Radio Bari was not effective in its political mission, as we will see later and in more detail. ${ }^{33}$

\section{Pre-Fascist Italy Cultural Diplomacy in Palestine}

In 1920 Chaim Weizmann, writing to Lord Curzon, noted that "in Palestine the Vatican and the Secular Italian Government seem to be identical. The cleavage that exists in Rome is not apparent in Jerusalem". ${ }^{34}$ Weizmann's observation was indeed right, for decades Italy struggled to establish a more permanent foothold in Palestine through Catholic institutions and clergy. By 1905, with Tommaso Tittoni as Foreign Minister, Italy officially adopted the same approach employed by the French that anticlericalism would never

\footnotetext{
${ }^{31}$ ASDMAE, Ap, Palestina, Busta 13, Roma, 4 November 1935. Jabotinsky was refused a meeting with Mussolini several times, however De Angelis wrote a memo suggesting that it was important to assist and favour Zionist revisionism as it was in the interests of the Italian government to support a form of Zionism clearly opposed to the official Zionism sponsored by the British government.

${ }^{32}$ ASDMAE, Ap, Palestina, Busta 8, Gerusalemme, 21 Mach 1934.

${ }^{33}$ Andrea Stanton, This Is Jerusalem Calling (Austin, TX: University of Texas Press, 2013), 94-101. The history of Radio Bari is also discussed by Marzano, Onde fasciste.

${ }^{34}$ Weizmann to Lord Curzon, 2 February 1920, The Letters and Papers of Chaim Weizmann, Vol. IX (Jerusalem: Israel University Press, 1977), 297-298.
} 
become un article d'exportation. ${ }^{35}$ In 1911 Senni suggested joining the concession to build a railway between Jerusalem and Beisan. His intention was to support the possible establishment of Italian agricultural settlements in Palestine; however, the proposal was not followed through because of the outbreak of the Italian-Ottoman war on Libya. ${ }^{36}$ The post-unitarian state did not have the funds or the expertise to really invest in Palestine as the British and the French did. Foreign policy in the region was an example of the rare collaboration between the Italian state-highly anticlerical-and pro-Catholic sectors within Italian society and politics. Italian diplomats in Jerusalem, regardless of their expertise and political affiliation, had a vested interest in the Catholic institutions operating in the region as they all recognised that the only way to establish a relevant presence was through Catholic institutions and Italian clergy. The idea was to undermine the traditional French position as protector of Catholics in the Holy Land. ${ }^{37}$

Italian consuls in Jerusalem operated in two ways: first they provided legal assistance required by Italian institutions, and secondly tried to financially support educational institutions and to facilitate the establishment of private Italian businesses. However, the reality was that a lack of funding and of an organic plan to develop an Italian presence in Palestine set the consuls on a collision course with the Italian government. As noted by Pieraccini and Fabrizio, the success of the Italian schools in Palestine was minimal, not only because of the lack of students but also because of the lack of clear knowledge of the region and support from Rome. The largest Italian community in Palestine, for instance, was to be found in Haifa, yet it was forgotten in favour of Jerusalem and Jaffa. ${ }^{38}$ This was indeed one of the limits of Italian diplomacy in Palestine, as its association with religious institutions did not allow Italian officials to see the potential for soft power where it was more likely to succeed.

Not much changed with the establishment of the Fascist regime in 1922. Mussolini was still as interested in building an empire in Africa as his liberal

\footnotetext{
${ }^{35}$ Paolo Pieraccini, "The External Cultural and Linguistic Policy of the Italian Government in the Mediterranean Region and the Issue of the National Association for Aid to Missionaries (1886-1905)," in Linguistic and Cultural Foreign Policies of European States: $18^{\text {th }}-20^{\text {th }}$ Centuries, eds. Karène Sanchez-Summerer and Willem Frijhoff (Amsterdam: Amsterdam University Press, 2017), 110 .

${ }^{36}$ ASDMAE, Busta 745, Ap. Miscellaneous, Senni to Di San Giuliano, Jerusalem, 30 May 1911.

${ }^{37}$ A good summary of the French work to protect and foster its position in Palestine is given by Dominique Trimbur, "Les Liuex Saints Chrétiens de Palestine comme Préoccupation de la Politique Extérieure Française (1917-1948)," in Diplomatie et Religion. Au Couer de l'Action Culturelle de la France an XXe Siècle, eds. Gilles Ferragu and Florian Michel (Paris: Publication de la Sorbonne, 2016), 173-189.

${ }^{38}$ In 1923 a petition was sent to Mussolini by the members of the Italian colony in Haifa suggesting they were a 'gregge senza pastore' (a people without a leader). ASDMAE, Affari Politici, Palestina, Pacco 1458, Fasc. 6292, petition of the Italian Patriotic Association Haifa, Haifa, 28 August 1923.
} 
predecessors. Rumours were circulating about the possibility of Rome taking over the Palestine Mandate, a notion supported by Catholics and nationalists, but there is no evidence suggesting Mussolini endorsed the idea, if the British would have ever thought of relinquishing their hold. ${ }^{39}$ The appointment of Orazio Pedrazzi as consul in Jerusalem in 1927 suggests a change of course in the Italian attempt to influence Palestine. Pedrazzi, who was a journalist and a so-called expert in Middle Eastern affairs, told Mussolini that there was a new Palestine emerging after the Great War: it was the Zionists who were going to change the country. Pedrazzi believed it was imperative for the Italians to deploy cultural diplomacy, and indeed economic measures, in order to work with the Jews "whether we like it or not". ${ }^{40}$ In the material perused so far, it is interesting to note that Pedrazzi essentially ignored Palestinian nationalism. Pedrazzi demonstrated the inconsistency of the Italian approach to Palestine: while openly supporting Zionism, he supported the Latin Patriarch Barlassina-openly anti-Zionist-but criticised the Pope and his approach towards the local Christian Churches. The Italian consul believed that the Vatican policy of supporting the local clergy and the Arabisation of the Church was an open challenge against the Italian character of Catholic institutions in Palestine. ${ }^{41}$ How, then, could a set of cultural policies be developed and implemented in light of this inconsistency? Liberals and early Fascists were all trapped into a loophole that limited any form of cultural diplomacy.

In order to show the limits and potential of Italian cultural diplomacy I present two small examples. The first case illustrates that despite the attention paid to cultural institutions like schools, consuls were better trained to care for the legal necessities of the same institutions. The second example shows the failure of the first fully funded and developed operation of cultural diplomacy through the opening of the Italian hospital in Jerusalem. Unfortunately, due to the war against the Ottomans over Libya in 1911 and later the outbreak of the First World War, the hospital never functioned as such and changed hands through the decades. Yet its architecture is still a visible sign of the attempt to influence Oriental culture.

\section{"La Strada Delle Suore”}

While perusing the papers of the Italian consulate in Jerusalem for the early years of the twentieth century it is striking to note how legal and other petty issues kept Italian officials busy. In 1901 the Italian government supported the opening of two colonial schools, one in Jaffa and one in Jerusalem. In order to avoid Ottoman restrictions on national institutions, Fr. Giannini,

\footnotetext{
${ }^{39}$ Arielli, Fascist Italy, 20.

${ }^{40}$ ASDMEA, Affari Politici, Busta 1460, Pedrazzi to Mussolini, Jerusalem, 19 May 1927.

${ }^{41}$ See Giorgio del Zanna, Roma e l'Oriente. Leone XIII e l'Impero Ottomano (Milan: Guerini e Associati, 2003), 290-330.
} 
the Custos of the Custody of the Holy Land, collaborated with the secular authorities in order to open these schools. ${ }^{42}$ While the school in Jerusalem never opened, the one in Jaffa was quite successful. The Italian authorities were hoping to create a school for Italians, but eventually the largest number of pupils were subjects of other countries, mainly local Ottomans. ${ }^{43}$ In 1912 consul Senni requested Italian flags for the schools in Palestine. The ministry eventually sent ten. ${ }^{44}$ These are indeed small examples of policies aiming at culturally influencing the region, yet the largest file in the same box is dedicated to a legal matter that may have compromised access to the Italian female school in Jaffa. In a sense this mirrors the weaknesses of Italian attempts at cultural diplomacy. Consular attention shifted often towards those areas in which they were most likely to be successful.

On 10 November 1910 Sister Maria Rufina, the superior of the Italian girls' school in Jaffa, contacted the Italian consul in Jerusalem reporting on a matter of urgency. This related to the attempt by Osman Nashashibi to close the road where the school was located in order to expand his property. ${ }^{45}$ The question was a legal one that included decisions taken by the municipality and the Meclis Idare (administrative council). ${ }^{46}$ The consulate provided Sister Rufina with legal and monetary help, yet Senni came to realise that the question was becoming a religious issue since the majority of the personnel at the administrative court in Jaffa was Muslim. Senni and the consular agent in Jaffa, Alonzo, also realised that there were internal political battles between the various administrative units and the Nashashibi family. The story is rather long and tedious but revealing of the low-level priorities of Italian officials in Palestine. Daniela Fabrizio is right to remind us that the Italian consuls until the end of the 1920s fully applied the principles of prudent initiatives and realistic ambitions: not exactly what was needed for the successful development of cultural diplomacy. ${ }^{47}$

\section{The Italian Hospital (Building)}

While busy with the "strada delle suore" in Jaffa, the Italian consul was also occupied with one of the most visible forms of cultural diplomacy employed

\footnotetext{
${ }^{42}$ ASDMAE, Pacco 11 (old catalogue), Italian Foreign Office to Italian Consul Scaniglia, Rome, 20 August 1900. More details about this are to be found in Fabrizio, Fascino D'Oriente, 285-290.

${ }^{43}$ ASDMAE, Italian Consulate Jerusalem, Busta 11, Fasc. 75.

${ }^{44}$ ASDMAE, Pacco 11 (old catalogue), Senni to Italian Foreign Office, Jerusalem, 16 December 1912. The reply from Tittoni to Senni, Rome, 7 March 1913.

${ }^{45}$ ASDMAE, Pacco 11 (old catalogue), Suor Maria Rufina to Carlo Senni, Jaffa, 10 November 1910 .

${ }^{46}$ Details of the administrative Ottoman structure can be found in Johann Büssow, Hamidian Palestine Politics and Society in the District of Jerusalem 1872-1908 (Leiden: Brill, 2011).

${ }^{47}$ Fabrizio, Fascino D’Oriente, 36.
} 
by the Italians: the construction of a hospital in the shape of a renaissance building, very similar to Palazzo Vecchio in Florence. ${ }^{48}$ This was a major diplomatic operation that required the consulate to deal with the Ottoman administration and with the Associazione per Soccorrere $i$ Missionari Italiani all'Estero (The National Association for Aid to Missionaries) that operated in lieu of the consulate. The history of the Italian hospital is a complicated one as its erection was first paused due to the Italian-Ottoman war over Libya in 1911, and later by the outbreak of the First World War. The hospital had been designed by the famous Italian architect Antonio Barluzzi, together with his brother Giulio, and was meant to bring a flavour of Italy to Palestine. ${ }^{49}$ Senni, writing to the Italian Ambassador in Constantinople in March 1915-just a few weeks before Italy joined the war-noted that the inauguration of the hospital had been postponed as a result of the war. ${ }^{50}$ Eventually the hospital changed hands several times before becoming part of the Israeli Ministry of Education after 1948. The virtual absence of information about this building and of literature dedicated to it is a sign of the failed attempt of the Italians to establish a health institution which was not only meant to provide medical attention to the local population and Italian residents, but through its design was meant to symbolise a visible Italian presence and influence.

\section{Fascist Cultural Diplomacy in Palestine 1934-1939}

On 18 March 1934 Mussolini, while delivering a speech to the Fascist Party assembly in Rome, stated: "of all the great Western Powers of Europe the nearest to Africa and to Asia is Italy. A few hours by sea, fewer still by air, suffice to join Italy to Africa and to Asia .... It is not a matter of territorial conquests ... but of a natural expansion which should lead to collaboration between Italy and the nations of the Near and Middle East". ${ }^{51}$

This is generally understood as the watershed of Italian activity in the Middle East: from reactive and limited intervention, to pro-active, visible and tangible forms of propaganda and direct involvement. Scholars, however are divided over the general assessment of Italian intervention in the Middle East in the 1930s. Italian academics tend to suggest that Arab nationalism and local Arab forces-as in the case of the Mufti of Jerusalem-were used as pawns in order to reach a general understanding with the British over

${ }^{48}$ ASDMAE, Italian Consulate Jerusalem, Busta 17, Fasc. 79, Ospedale di Gerusalemme.

${ }^{49}$ Masha Halevi, "A Pious Architect and an Italian Nationalist: Antonio Barluzzi and His Activism in Promoting the Italian Interests in the Holy Land," Cathedra 144 (2012): 75-106 (Hebrew).

${ }^{50}$ ASDMAE, Pacco 11 (old catalogue), Senni to Marchese Garroni, Jerusalem, 20 March 1915.

${ }^{51}$ India Office Record (IOR), L/PS/12/107/2629, 'Mussolini's speech at the Quinquennial Fascist Assembly,' Rome, 18 March 1934. 
control of the Mediterranean. More recent Italian scholarship and AngloSaxons historians, on the other hand, argue that Mussolini had real imperial aspirations in the Mediterranean, seeking to make Italy a hegemonic power in the Middle East. ${ }^{52}$ While I cannot here engage in the interpretation of Fascist policies in the region, I believe Mussolini certainly tried to reach a general understanding with the British, but in the end Fascism was an imperialist ideology as suggested by the implementation of a series of cultural policies with the intent of favouring Italian imperial expansion. The major shift that occurred between 1933 and 1934 saw Mussolini and Fascist Italy supporting Arab nationalism and the rise of pro-Muslim policies. It is important to remember that this change has to be contextualised within the Fascist attempt to reconquer and legitimise rule over Libya. Since 1934 the Italian governor of Libya, Italo Balbo, pursued pro-Muslim policies in order to pacify the country and effectively gain consensus. These ranged from opening new mosques to maintaining high levels of hygiene in Islamic schools. Essentially these policies were designed to turn Libya from a source of embarrassment to source of pride for Italy. ${ }^{53}$ The link between Libya and Palestine was a loose one and interests were different as Libya needed to remain calm, while Palestine should be "set on fire" in order to challenge the British. Yet, pro-Muslim policies in Libya certainly had the effect of showing Palestinian Muslims Italy's goodwill and different colonial style.

The inconsistency of this approach, however, was of a greater magnitude. In 1934, while Mussolini began to flirt with Arab nationalists, including Hajj Amin al-Husayni in Jerusalem, he also met the leaders of the Zionist Movement including Chaim Weizmann. At some points Mussolini had no problems calling himself both the protector of Islam and the protector of the Jews. ${ }^{54}$ However, throughout the 1920s Italian cultural activities also focussed on winning the hearts of local Christians in order to showcase "the new Italy" created in the post-war era. ${ }^{55}$ This might have been true in general, but looking at Palestine we can certainly see a total lack of understanding, knowledge and relationships with the Melkite Church. Despite representing the largest local Arabic-speaking Catholic community, they were largely ignored. While defending the Italian character of the Catholic Church in Palestine, Italians essentially missed an opportunity to develop forms of cultural influence which might have found fertile ground. While this chapter cannot present a full analysis and assessment of Fascist cultural policies in

\footnotetext{
${ }^{52}$ A good summary of this debate is in Arielli, Fascist Italy, 1-3.

${ }^{53}$ Arielli, Fascist Italy, 96-97.

${ }^{54}$ Claudio Segré, "Liberal and Fascist Italy in the Middle East, 1919-1939," in The Great Powers and the Middle East 1919-1939, ed. Uriel Dann (New York: Holmes and Meier, 1988), 207.
}

${ }^{55}$ M. G. Pasqualini, Gli Equilibri nel Levante (Palermo: Edizioni Associate, 1995), 146; M. Tedeschini Lalli, "La Propoganda Araba del Fascismo e l'Egitto," Storia Contemporanea 7, no. 6 (1976): 722 . 
Palestine, I briefly show two examples demonstrating the weakness of Italian cultural propaganda, bearing in mind that the failure of Italian Fascist cultural diplomacy was not a weakness on its own but part of the larger failure of Fascist foreign politics. The first example is Radio Bari and the second one Italian relations with Zionism and the Jewish community in Palestine.

\section{Radio Bari}

Radio Bari was established in 1932 during the third Levant Fair, with an original purpose of broadcasting in Albanian and Greek, showing a clear interest in the Balkans. ${ }^{56}$ Broadcasts in Arabic began only in 1934 as a result of the changing attitude of the Fascist regime towards North Africa and the Middle East. The purpose of these broadcasts was to increase Italian influence in the Mediterranean and throughout the Middle East and secondly to strengthen the ties between Italy and the Arab people. ${ }^{57}$ Theses radio shows certainly fall into the category of cultural propaganda, as Italians were trying to restore their image in the Arab-Islamic world following the Senussi massacres, and secondly they wanted to show their interest in the region despite the attempt by Britain and France to overshadow Italy and the Fascist regime. ${ }^{58}$ The newscast aired on 24 May 1934, for instance, included a discussion of the Arab Fair in Jerusalem, emphasising its positive results and large attendance - a clear attempt to gain local attention. ${ }^{59}$ There is a good body of literature on Radio Bari, however the only full analysis has been provided in Italian by Arturo Marzano who argued that we should think about Radio Bari and its broadcasts in terms of soft power. ${ }^{60}$ Radio Bari became the flagship of Italian propaganda in the Middle East and crucially in Palestine which was getting closer to a major outbreak of violence. The lack of competition, as noted by scholars discussing Radio Bari, essentially enabled Italians to reach large audiences. Is this a good criterion to look at the level of influence? Obviously not. For instance the popular Palestinian newspaper Filastin in an article published in 1938-when the Arab Revolt was already raging in Palestine-suggested that Arabic-language programs were welcomed, yet "the worst that we ate of this propaganda is the allegation that Radio Bari [has] all that influence over the movement in Palestine". ${ }^{61}$

${ }^{56}$ Marzano, Onde Fasciste, 44.

${ }^{57}$ Callum A. MacDonald, "Radio Bari: Italian Wireless Propaganda in the Middle East and British Countermeasures 1934-38," Middle Eastern Studies 13, no. 2 (May 1977): 195.

${ }^{58}$ MacDonald, "Radio Bari", 195.

${ }^{59}$ Marzano, Onde Fasciste, 45; on the Arab Fair in Jerusalem see the chapter by Nisa Ari in this volume and Nadi Abusaada, "Self-Portrait of a Nation: The Arab Exhibition in Mandate Jerusalem, 1931-34," Jerusalem Quarterly, no. 77 (2019): 122-135.

${ }^{60}$ Marzano, Onde Fasciste, 19.

${ }^{61}$ Filastin, "We Do Not Need This or That," January 7, 1938. (Arabic). 
In the end Radio Bari does not appear to have played a key role in turning Palestinians against the British. ${ }^{62}$ While from 1935 broadcasts became more and more anti-British in nature, possibly causing the audience to turn away from Italian propaganda, Radio Bari did not lose its appeal as the cultural shows aired were still favoured by Arab listeners. ${ }^{63}$ These broadcasts included lectures from al-Azhar scholars on the history of Islam and legal topics. A number of conversations, in Arabic, discussed Italian and Arabic literature. The largest audience was probably captured through music as Radio Bari played a mix of Italian, classical and Arabic music, including numerous hits by Umm Kulthum. ${ }^{64}$ These broadcasts were part of the pro-Muslim policies enacted in Libya and the Islamic world in order to gain support by showing the good face of Italian colonialism. Broadcasts were also followed by the activity of local Italian officials. For instance the Italian consul Quinto Mazzolini, in December 1936, was able to avoid the publication by $A l$ - Jamayya al-Islamiyya-published in Jaffa-of a special issue attacking Italian colonialism in Abyssinia. ${ }^{65}$ In 1937 Mazzolini tried once again to win the hearts of the Palestinians by suggesting free access to the agricultural and crafts schools in Italian Africa for Palestinians. ${ }^{66}$ The response was negative as the governor of Libya, Balbo, believed that bringing Palestinians to Libya might have inflamed local nationalism, showing that political propaganda was a dangerous business. ${ }^{67}$

While political propaganda essentially failed, cultural broadcasts proved to be very successful. The high standard of entertainment and the attention to the Arabic used proved to be very effective for Radio Bari. The British, as they themselves admitted, were simply not capable of keeping up with the quality of the shows. ${ }^{68}$ Italy was indeed succeeding in presenting its new image as a positive one. Radio Bari was able to air programs that would merge Italian and Arabic culture together, yet we need to remember that Italians looked at Arabs with a sense of Orientalism that often, as noted by Marzano, blended the various broadcasts: in other words cultural diplomacy was once again a one-way direction. ${ }^{69}$ Italy embarrassed London as their

${ }^{62}$ Stanton, This Is Jerusalem Calling, 100.

${ }^{63}$ MacDonald, "Radio Bari," 195-207.

${ }^{64}$ See Marzano, Onde Fasciste, 181-197.

${ }^{65}$ ASDMEA, Affari Politici, Palestina, Busta 30. Mazzolini to Foreign and Propaganda Ministries, Jerusalem, 4 December 1936.

${ }^{66}$ ASDMEA, Affari Politici, Palestina, Busta 15, Mazzolini to Foreign Ministry, Jerusalem, 27 May 1937.

${ }^{67}$ ASDMEA, Affari Politici, Palestine Busta 15, Ciano to Mazzolini, Rome, 29 October 1937.

${ }^{68}$ TNA PRO FO 395/560, 'BBC: Overseas Intelligence Department' and TNA PRO FO 395/561, 'The British Broadcasting Corporation: The Arabic Broadcasts', London, September 1938.

${ }^{69}$ Marzano, Onde Fasciste, 180. 
programs were better and more successful, yet I would argue that focussing on "la bella figura" - the appearance rather than the impact-did not bring any positive result. While their broadcasts may have been indeed very good, they never scratched the surface and Italy was never seriously considered to replace Britain in Palestine.

\section{The Protector of the Jews}

As mentioned above, in the early years of the Fascist regime Mussolini looked upon Zionism with some favour. He met the leading figures of the Zionist movement and several times made statements suggesting Italy was in favour of the establishment of a Jewish entity in Palestine. ${ }^{70}$ Things obviously changed in 1938 with the adoption of racial laws against the Jews, but more importantly in our context with the massive increase of anti-Semitic propaganda spread through Radio Bari. ${ }^{71}$ Anti-Semitism was not unknown in Italy before 1938, but it often remained within Catholic circles.

In this section I want to show the attempts made by the Italian government to create a cultural nexus with the Jewish-Zionist community in Palestine. As we saw earlier the major shift occurred with the appointment of Orazio Pedrazzi as consul in Jerusalem. The Zionist press believed Pedrazzi to be anti-Zionist as proven by the large number of articles published in several languages upon his appointment. ${ }^{72}$ Pedrazzi, as mentioned earlier, realised the importance of collaborating with the Zionists if the Italians were to have some sort of influence in the region. The idea of establishing a network of Italian Jewish institutions around the Mediterranean, with an Italian school in Jerusalem, predates the arrival of Pedrazzi. ${ }^{73}$ However Italian Jews were not well organised, and these ideas remained as such.

The material in the archives of the Italian consulate in Jerusalem offers us a snapshot of various cultural operations designed by the Italians to strengthen their position in Palestine through the Zionist movement. For instance the Italians participated with a pavilion at the Levant Fair in Tel Aviv between 1934 and 1939. ${ }^{74}$ In 1935 Consul De Angelis and the President of the

\footnotetext{
${ }^{70}$ An interesting chapter on Mussolini and Zionism has been written by De Felice who argued that Mussolini distinguished between Italian Zionism and International Zionism, the first was to be mistrusted, the latter to be supported. Renzo de Felice, Il Fascismo e l'Oriente (Padua: Luni Editrice, 2018), 125-186 (reprint).

${ }^{71}$ Marzano, Onde Fasciste, 209-232.

${ }^{72}$ For Instance: Palestine Bullettin, "Signor Pedrazzi Defines His Attitude Towards British Mandate and Zionism," Jerusalem, 15 April 1927; Israël, 'L'Italie et la Palestine', 6 May 1927; The Sentinel, "Italian Fascism and its Attitude to Zionism," 13 May 1927.

${ }^{73}$ Fabrizio, Fascino D’Oriente, 374-376.

${ }^{74}$ ASDMAE, Italian Consulate Jerusalem, Fasc. 190, Busta 28, 'Fiera del Levante a Tel Aviv 1935-1939.'
} 
Italian Chamber of Commerce in Jerusalem, Ruffo, argued that Italy should invest in a visible presence considering that Jewish Palestinian industry was going to be present at the Levant Fair in Bari. ${ }^{75}$ Eventually Italy did not participate in 1936 as a result of the international sanctions following its invasion of Ethiopia, yet Italians were still very much interested and in 1937 once again displayed their products. ${ }^{76}$ One may wonder why this participation was important for the Italian regime. Perhaps this was part of the larger effort to expand Italian influence; besides, Mussolini, while visiting the Levant Fair in Bari in 1934, "displayed deep interest in the exhibit of Palestine products and asked for detailed information on the development of Tel Aviv, the new harbour at Haifa and on the situation of the German Jews in Palestine". ${ }^{77}$

While economic activities followed the international context, cultural diplomacy was much more unrestricted. Unsolicited, Professor Chaim Wardi wrote on 25 June 1931 from Turin to the Italian consul in relation to the possibility of opening an Italian cultural centre in Tel Aviv. The same idea was expressed by Nahum Labunsky. ${ }^{78}$ The initiative was also supported by the mayor of Tel Aviv, Dizengoff. It is quite obvious that the Italian government was trying in some way to tap into the Zionist movement, however it was also clear that this was part of a larger effort to develop forms of Italian cultural penetration in Palestine. ${ }^{79}$ While De Angelis investigated Wardi and Labunsky, he was able to gather the necessary funds to open an Italian Library in Tel Aviv. On 30 December 1932 the Circolo degli Amici della Cultura Italiana was officially established in Tel Aviv, including a small library in 46 Jona Hanovi Street. ${ }^{80}$ A year later De Angelis acknowledged the success of the operation, however he also asked for more material to be sent to the Italian library as it would be beneficial to the circulation of Italian culture and fascist ideology in Palestine. ${ }^{81}$ While the extent of the success of the Circolo and the library is not clear, we may speculate it had some impact on the Jews of Tel Aviv considering the various activities promoted, ranging from academic lectures to entertainment like music and dances. In 1938 the

${ }^{75}$ ASDMEA, Italian Consulate Jerusalem, Fasc. 190, Busta 28, De Angelis to Foreign Office Rome, Jerusalem, 21 August 1935.

${ }^{76}$ ASDMAE, Italian Consulate Jerusalem, Fasc. 190, Busta 28, De Angelis to the Direction of the Levant Fair, Jerusalem, 15 May 1936.

${ }^{77}$ Jewish Daily Bulletin, New York, September 7, 1934.

${ }^{78}$ ASDMAE, Italian Consulate Jerusalem, Fasc. 415, Busta 53, Chaim Wardi to Italian Consul, Turin, 25 June 1931. See also Labunsky to Italian Consul, Rome, 27 June 1931.

${ }^{79}$ ASDMAE, Italian Consulate Jerusalem, Fasc. 415, Busta 53, 'Circolo degli Amici della Cultura Italiana' 1931-1934.

${ }^{80}$ ASMAE, Italian Consulate Jerusalem, Fasc. 415, Busta 53, Report on the opening of the 'Circolo degli Amici della Cultura Italiana,' Tel Aviv, 30 December 1932. Honorary president was the Consul, Vice President Yakir Behar, Secretary Nahum Labunsky and Treasurer Chaim Wardi.

${ }^{81}$ ASMAE, Italian Consulate Jerusalem, Fasc. 415, Busta 53, De Angelis to Foreign Office Rome, Jerusalem, 24 January 1933. 
Circolo degli Amici closed as a result of the racial laws: funding and material were diverted to the opening of the Dante Alighieri Cultural Institute.

Parallel to the activities of the Circolo is the offer made by Israel Heller, a Palestinian-Jewish student at the University of Pavia, who contacted the secretary of the Fascist Student Organisation in Milan in 1932. ${ }^{82}$ Heller was offering to spread cultural propaganda to the Jews and non-Jews of Palestine, in order to disseminate fascist values and to make Italian fascism known abroad through the creation of "circoli" (clubs). The proposal was evaluated at the highest levels of the fascist government, yet the Italian vice-consul in Haifa, D'Acunzo, and the general consul in Jerusalem, Gabrielli, while praising Heller, acknowledged the complex divisions emerging in Palestine. Gabrielli made it clear that considering the demographics, it was important for the Italians to influence the Zionist movement, but at the same time not to show clear support for it. ${ }^{83}$ While Gabrielli believed the action of individuals was important, the consul insisted that Italian cultural propaganda should be developed through the existing institutions-including the Circolo degli Amici della Cultura Italiana-but more importantly through Jewish schools where fascism could be spread while teaching Italian. Gabrielli openly acknowledged that it was important to link fascism with the revisionist ideas of Jabotinsky. Italians indeed invested a considerable amount of money and efforts in teaching Italian in Jewish schools, however in 1938 with the promulgation of the racial laws the relationship between the Italian government and Zionist-Jewish organisations and institutions in Palestine ceased, showing once again the inconsistency of Italian cultural diplomacy.

\section{CONCLUSION}

From the 1930s onwards Italian cultural efforts and propaganda in Palestine created a lively buzz among Arabs and Jews: Italy was talked about a great deal. Movies, newsreels, magazine, newspapers, cultural events and Radio Bari broadcasts reached a vast audience, yet, as Claudio Segré argued "to be talked about is not necessarily to be respected or admired". ${ }^{44}$ Italian cultural activities were not well organised nor well supported despite the various claims made by Italian politicians both in the liberal era and later under the aegis of Fascism. The years between 1936 and 1939 are a good case study as Italian diplomacy certainly worked hard to support the Palestinian Revolt both financially and through propaganda, yet back in Italy the Catholic press published angry articles against the Revolt, which was described as an example of Islamic fanaticism. It is not a surprise, then, that this inconsistency eventually led to

\footnotetext{
${ }^{82}$ ASDMAE, Italian Consulate Jerusalem, Fasc. 417, Busta 54, 'Proposte Propaganda Fascista dello Studente Israel Heller,' 1932. Letter to Andrea Ippolito, Milan, 3 February 1932.

${ }^{83}$ ASMAE, Italian Consulate Jerusalem, Fasc. 417, Busta 54, Gabrielli to Foreign Office Rome, Jerusalem, 27 May 1932.

${ }^{84}$ Segré, "Liberal and Fascist Italy," 209.
} 
the failure of Italian support for the Palestinian Revolt. Besides, despite many believing that Palestinians were supporting Italy, the reality was that this was a myth, as proven by the numerous articles published by the Palestinian press against Italian political activities. It is fair to say that from 1935 onwards some newspapers adopted a more positive attitude towards Italy, yet this was dictated more by the principle of "the enemy of my enemy is my friend" than a genuine support for Italy and its Fascist regime. Filastin in 1936 argued: "The Arabs do no trust Italy and even hate it. However, it is certainly possible to negotiate with Italy and to reach an agreement". 85

While political influence proved to be a failure, I would argue that the deployment of soft power may not have produced the desired outcomes as a result of the visible inconsistencies and lack of appropriate support. However, the failure of Italian cultural diplomacy in the 1930s did not mean its full demise both in the short and long term. For instance, Italian is still a dominant language among the Catholic institutions in Palestine, and both the Custos and Latin Patriarch are still Italian. However, Italian cultural institutions cannot be compared to the quantity and quality of their British, American and French counterparts. Italians still rely on the work of EU institutions rather than their own. The concept of "bella figura" mentioned earlier seems to be still the leading principle of Italian cultural diplomacy in Palestine as shown by the amazing restoration of the Is'af al-Nashashibi Villa in East Jerusalem by the University of Pisa, now hosting Dar Issaf Nashashibi for Culture and Literature. ${ }^{86}$ While the restoration is certainly visible, Italian influence remains limited.

Lorenzo Medici in 2008 argued that: "Italian cultural policy had remarkable success in this region. After the birth of the Italian Kingdom, particular attention had been paid to the Mediterranean, where, because of the presence of important Italian communities and, later, Fascist imperial ambitions, Italy improved relevant cultural relations". ${ }^{87} \mathrm{I}$ am not entirely sure how he might have reached this conclusion, as if any success was achieved, it was the consistent inconsistency of Italian cultural policies throughout the decades and political regimes.

\section{BIBLIOGRAPHY}

Abusaada, Nadi. "Self-Portrait of a Nation: The Arab Exhibition in Mandate Jerusalem, 931-34." Jerusalem Quarterly, no. 77 (2019): 122-135.

Ang, Ien, Yudihishthir Isar, and Philp Mar. "Cultural Diplomacy: Beyond the National Interest?" International Journal of Cultural Policy 21, no. 4 (2015): 365-381.

${ }^{85}$ Filastin, November 7, 1936.

${ }^{86}$ See https://librarianswithpalestine.org/featured-projects-members/family-libraries/issafnashashibi-center-for-culture-and-literature/, last modified March 1, 2019.

${ }^{87}$ Lorenzo Medici, "Western Cultural Policy in the Mediterranean during the $20^{\text {th }}$ Century," in Mediterranean Europe, ed. Marta Petricioli (Brussels: Peter Lang, 2008), 317. 
Arielli, Nir. Fascist Italy and the Middle East 1933-40. London: Palgrave Macmillan, 2010 .

Buffon, Giuseppe. Les Franciscains en Terre Sainte (1869-1889). Religion et politique: une recherche institutionelle. Paris: Cerf, 2005.

Büssow, Johann. Hamidian Palestine Politics and Society in the District of Jerusalem 1872-1908. Leiden: Brill, 2011.

De Felice, Renzo. Il Fascismo e l'Oriente. Padua: Luni Editrice, 2018. [Reprint].

Della Seta, Simonetta. "La Presenza e l'Opera dei Salesiani in Palestina." Storia Contemporanea 20, no. 1 (1989): 81-101.

Del Zanna, Giorgio. Roma e l'Oriente. Leone XIII e l'Impero Ottomano. Milan: Guerini e Associati, 2003.

Fabrizio, Daniela. Fascino D'Oriente. Religionie Politica in Medio Oriente da Giolitti a Mussolini. Genoa: Marietti, 2006.

. Identita’ Nazionali e Identita’ Religiose. Rome: Studium, 2004.

Ferrari, Silvio. Vaticano e Israele dal secondo conflitto mondiale alla guerra del Golfo. Florence: Sansoni, 1991.

Gabellini, Andrea. L'Italia e l'assetto della Palestina (1916-1924). Florence: Societá per gli studi sul Medio Oriente, 2000.

Gienow-Hecht, Jessica C. E. and Mark C. Donfried. "The Model of Cultural Diplomacy." In Searching for a Cultural Diplomacy, edited by Jessica C. E. Gienow-Hecht and Mark C. Donfried. Oxford: Berghahn Books, 2010.

Giovannelli, Andrea. La Santa Sede e la Palestina: La Custodia di Terra Santa tra la fine dell'impero ottomano e la guerra dei sei giorni. Rome: Studium, 2000.

Halevi, Masha. "A Pious Architect and an Italian Nationalist: Antonio Barluzzi and His Activism in Promoting the Italian Interests in the Holy Land." Cathedra 144 (2012): 75-106. (In Hebrew).

Kessel, T. van. Foreign Cultural Policy in the Interbellum: The Italian Dante Alighieri Society and the British Council Contesting the Mediterranean. Amsterdam: Amsterdam University Press, 2016.

MacDonald, Callum. "Radio Bari: Italian Wireless Propaganda in the Middle East and British Countermeasures 1934-38.” Middle Eastern Studies 13, no. 2 (May 1977): 195-207.

Marzano, Arturo. Onde Fasciste. La Propaganda Araba di Radio Bari 1934-43. Rome: Carocci, 2015.

- Una terra per rinascere: Gli ebrei italiani e l'emigrazione in Palestina prima della guerra (1920-1940). Genoa: Marietti, 2003.

Medici, Lorenzo. "Western Cultural Policy in the Mediterranean during the $20^{\text {th }}$ Century." In Mediterranean Europe, edited by Marta Petricioli. Brussels: Peter Lang, 2008.

Minerbi, Sergio. Il Vaticano, la Terra Santa e il Sionismo. Milan: Bompiani, 1988.

Nye, Joseph. Soft Power. The Means to Success in World Politics. Cambridge: Perseus Books, 2004.

Pasqualini, M. G. Gli Equilibri nel Levante. Palermo: Edizioni Associate, 1995.

Pieraccini, Paolo. Cattolici di Terra Santa (1333-2000). Florence: Pagnini e Martinelli, 2003.

- Il ristabilimento del patriarcato latino di Gerusalemme e la custodia di Terra Santa. La dialettica istituzionale al tempo del primo patriarca mons. Giuseppe Valerga (1847-1872). Cairo: Franciscan Center of Christian Oriental Studies, 2006. 
"The External Cultural and Linguistic Policy of the Italian Government in the Mediterranean Region and the Issue of the National Association for Aid to Missionaries (1886-1905)." In Linguistic and Cultural Foreign Policies of European States: $18^{\text {th }}-20^{\text {th }}$ Centuries, edited by Karène Sanchez Summerer and Willem Frijhoff. Amsterdam: Amsterdam University Press, 2017.

Piola Caselli, Giuseppe Alessandro. Cronache Marinare (1843-1883), edited by Federico Adamoli. www.piolacaselli.altervista.org/cronache-marinare/ Cronache\%20Marinare\%20con\%20Indice.pdf.

Riccardi, Luca. Il "problema Israele": Diplomazia italiana e PCI di fronte allo stato ebraico (1948-1973). Milan: Guerini e Associati, 2006.

Rostagno, Lucia. Terrasanta o Palestina? La Diplomazia Italiana e il Nazionalismo Palestinese (1861-1939). Rome: Bardi, 1996.

Segré, Claudio. "Liberal and Fascist Italy in the Middle East, 1919-1939." In The Great Powers and the Middle East 1919-1939, edited by Uriel Dann. New York: Holmes and Meier, 1988.

Sharkey, Heather J. Muslims, Christian, and Jews in the Middle East. Cambridge: Cambridge University Press, 2017.

Singh, J. P. "Global Cultural Policies and Power." In International Cultural Policies and Power, edited by J. P. Singh. London: Palgrave Macmillan, 2010.

Stanton, Andrea. This Is Jerusalem Calling. Austin: University of Texas Press, 2013.

Tedeschini Lalli, M. "La Propaganda Araba del Fascismo e l'Egitto." Storia Contemporanea 7, no. 6 (1976): 717-749.

Trimbur, Dominique. "Les Lieux Saints Chrétiens de Palestine comme Préoccupation de la Politique Extérieure Française (1917-1948)." In Diplomatie et Religion. Au Coner de l'Action Culturelle de la France au XXe Siècle, edited by Gilles Ferragu and Florian Michel, 173-189. Paris: Publication de la Sorbonne, 2016.

Trimbur, Dominique, and Ran Aaronsohn. De Bonaparte a' Balfour. La France, l'Europe occidentale et la Palestine, 1799-1917. Paris: CNRS Editions, 2008.

Walter, Michael J. "Cultural Diplomacy, Political Influence, and Integrated Strategy."

In Strategic Influence: Public Diplomacy, Counterpropaganda, and Political Warfare, edited by M. J. Waller. Washington, DC: Institute of World Politics Press, 2009.

Open Access This chapter is licensed under the terms of the Creative Commons Attribution 4.0 International License (http://creativecommons.org/licenses/ by/4.0/), which permits use, sharing, adaptation, distribution and reproduction in any medium or format, as long as you give appropriate credit to the original author(s) and the source, provide a link to the Creative Commons license and indicate if changes were made.

The images or other third party material in this chapter are included in the chapter's Creative Commons license, unless indicated otherwise in a credit line to the material. If material is not included in the chapter's Creative Commons license and your intended use is not permitted by statutory regulation or exceeds the permitted use, you will need to obtain permission directly from the copyright holder.

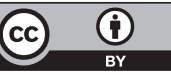

